\title{
Job Description of Family Planning Field Officers in the Decrease of Total Fertility Rate (TFR) in Population Control and Family Planning Department
}

\author{
Widia Astuti Tanjung, ${ }^{1}$ Heru Santosa ${ }^{2}$, Kintoko Rochadi ${ }^{3}$ \\ ${ }^{1}$ Master Student in Department of Administration and Health Policy, Universitas Sumatera Utara, Medan, \\ Indonesia \\ ${ }^{2}$ Lecturer in Department of Biostatistics and Population, Universitas Sumatera Utara, Medan, Indonesia \\ ${ }^{3}$ Lecturer in Department t of Health Promotion and Behavioral Sciences, Universitas Sumatera Utara, \\ Medan, Indonesia \\ Email: widiaastutitanjung@gmail.com
}

\begin{abstract}
:
Performance of Family Planning Field Officers can be seen by achieving the number of TFR, in accordance with the national target of 2.4. The total TFR of Sibolga city in 2016 was 2.6. Sibolga City is a city that consists of 4 districts and 17 villages. Sibolga City has 31 Family Planning Field Officers. The purpose of this study is to determine the performance of Family Planning Field Officers to reduce the total fertility rate. This type of research is qualitative with a phenomology approach. The results shows that the performance of Family Planning Field Officers in Population Control and Family Planning Department of Sibolga City PPKB Office is still not optimal. This is marked by the performance evaluation carried out and monitored only through social media chat groups, but the implementation of direct monitoring is still not good, there are gaps in report data in the field found by the difference in the number of Family Planning participants in the field with the number of Family Planning participants in Population Control and Family Planning Department Office, delays in sending reports, the number of human resources has exceeded the provisions but the TFR target has not been achieved, PLKB skills in counseling are still lacking, Population Control and Family Planning Department work discipline is still often violating things such as being late for work and leaving the workplace without a clear reason. This study recommends that Population Control and Family Planning Department conduct routine monitoring of Population Control and Family Planning Department in the Family Planning Health Center, provide training to PLKB in terms of counseling, give rewards to the districts with the lowest TFR, conduct scheduled outreach to the community regarding family planning programs in terms of reduction TFR number.

Keywords:

performance; family planning field officer; Total Fertility Rate (TFR)
\end{abstract}

\section{Introduction}

The high rate of population growth that occurs is a problem faced by Indonesia, so it needs serious attention and treatment from all parties. Based on population census data in 2017 Indonesia's population of 261 million increased from 2016, Indonesia has a population of $258,704,986$ people. Indonesia's population from 2012-2014 population growth continues to increase, from 3.59 million per year to 3.70 million per year. Based on the estimation results, the most population is in the Province of West Java with a population of 47,379,389 inhabitants, East Java at 39,075,152, Central Java at 34,019,095 and North Sumatra at 14,102,911. While the smallest population is found in North Kalimantan with a total of 666,333 inhabitants (Ministry of Health Republic of Indonesia, 2017). 
The National Family Planning Program is one of the basic programs which is very important for the progress of a nation. Population Control and Family Planning Department functions to provide services to the community by inviting, nurturing and motivating every family to join Family Planning program in accordance with National Population and Family Planning Agency Vision. The success of Family Planning program so far has been inseparable from the role of Population Control and Family Planning Department officers.

The population of Sibolga city of in the last six years from 2012 to 2017 continues to increase from year to year. In 2017 the population increased higher than the previous year which was 87,385 inhabitants (Population Control and Family Planning Department, 2017).

Based on RI Law number 87 of 2014 concerning Population Development and Family Development, Family Planning is an effort to regulate child birth, ideal birth spacing and age, regulate pregnancy, through promotion, protection, and assistance in accordance with reproductive rights to create quality families.

Sibolga City consists of 4 districts, 17 villages. With the total number of Population Control and Family Planning Department 31 people, it should have been maximized and can foster 1-2 villages and show maximum results because they already have the maximum number of Population Control and Family Planning Department.

Afniyanty's research (2016) on the performance of Family Planning Field Officers in Pakawa village, Pasangkayu subdistrict, North Mamuju district stated that things that affect the performance of Population Control and Family Planning Department in the field are limited management capabilities, inadequate work performance, ratio of family planning counselors or family field officers Planning on the number of villages built is not right, there is still a lack of Population Control and Family Planning Department operational funds.

The reality on the field shows that family planning field officers send reports as desired rather than in accordance with the facts on the ground, the monitoring function is very minimal so that Population Control and Family Planning Department can make reports that are not in accordance with the facts on the field but only to meet targets and the lack of supervision conducted in terms of activities that is only sent via the WhatsApp group if it pleases otherwise it doesn't matter, the number of Population Control and Family Planning Department has exceeded the target but has not been able to reach the agreed target, the data that are made annually are still incorrect and are still careless, supervision conducted by the level II only once a month is caused by the distance traveled from the service center to level II (Population Control and Family Planning Department).

Based on the description above, the authors are interested in conducting research on the performance of family planning field officers in decreasing the Total Fertility Rate (TFR) in the working area of Population Control and Family Planning Department Sibolga City in 2017.

\section{Research Method}

This type of research is descriptive with a phenomology approach. This research was conducted at the Population and Family Planning Control Office in Sibolga City with a research period from March to August 2018. Informants were determined purposively based on consideration that they were considered to be able to provide data and information about the Family Planning Field Officers performance in Population Control and Family Planning 
Department Sibolga City. Data collection in this research is to obtain primary and secondary data through documentation and interview data collection techniques. To facilitate data management and discussion, a research concept definition is formulated, namely:

a. Performance is the result of work that has been achieved by Family Planning Field Officers in Sibolga City adjusted to existing targets.

b. Total Fertility Rate (TFR) is the average number of children born to women of childbearing age (15-49) years in an area in particular time.

\section{Discussion}

\subsection{Result}

The results were obtained based on qualitative interviews and documentation which were divided into two groups namely, structural officials, Family Planning Field Officers, and the community. Based on the statement of the structural officials of Family Planning Field Officers, to monitor Family Planning Field Officers performance in their field only by looking at the work plan in which there is a schedule to go to the field then the evidence going to the field is sent to the WhatsAap group. Further information Population Control and Family Planning Department stated that sometimes the photos that were sent were only 15 people who took part in the activities while the cadre had almost 15 people, meaning that only a small number of people participated in the event.

Reports received by Population Control and Family Planning Department every month are F1DAL reports, F2 Family Planning, Warehouse Reports, Family Planning Participant Reports, etc. The performance of Family Planning Field Officers is only assessed from the report, while the report itself is made only on paper. The results of the interview found that the Family Planning Field Officers acknowledged that the reports sent every month had to be good in numbers so that our performance was also good, meaning that the data created did not match the events on the ground just to reach the target.

The monitoring of Family Planning Field Officers performance is carried out by looking at Family Planning Field Officers work plan that has been scheduled and absent from Family Planning Field Officers every morning and evening. Population Control and Family Planning Department checks directly to the Family Planning Counseling Center, the PPKB Office also has a WA group with Family Planning Field Officers. But when they went down in the field, Population Control and Family Planning Department often found many Family Planning Field Officers leaving the Bernacana Family Counseling Center for no apparent reason. When absent in the morning and evening there were also Family Planning Field Officers who were absent. This is due to the absence of sanctions made by Population Control and Family Planning Department Sibolga.

The results of in-depth interviews with family planning officers regarding the discipline of Family Planning Field Officers were not yet disciplined in carrying out their main tasks and functions. It is better for Family Planning Field Officers to have high discipline because if it has automatic discipline, it will have a great sense of responsibility for the work it entails so that the Family Planning Field Officers is able to position itself as a good public servant and always set a good example for the community it serves.

The number of Family Planning Field Officers in the city of Sibolga has actually exceeded the ideal number. One Family Planning Field Officers person should be responsible for 1 subdistrict. The number of Family Planning Field Officers of Sibolga city is 31 people while the 
number of outflows in Sibolga City is only 17 villages, but this cannot be used as a benchmark to see the success of Family Planning Field Officers performance.

Family Planning Field Officers conducts outreach when it runs the Toddler Family Development program, Elderly Family Development, Youth Family Development. Counseling is usually done at Posyandu, Family Planning Counseling Centers, Lurah Offices, and Schools. The steps taken by Family Planning Field Officers are not optimal because there are still people who do not understand about family planning activities in the city of Sibolga. There are still people who have never heard of the word Family Planning Field Officers and have never known Family Planning Field Officers in their neighborhood.

\subsection{Discussion}

The discussion was conducted to analyze the main problems related to the research objectives, namely to analyze the performance of the Family Planning Field Officer in decreasing the Total Fertility Rate in Population Control and Family Planning Department Sibolga City.

Based on the research results obtained that monitoring the performance of Family Planning Field Officers is done by checking directly and forming a social media group using the WhatsApp (WA) application. The Family Planning Counseling Office rated by Population Control and Family Planning Department has the best performance, namely the Family Planning Counseling Center in Sibolga Selatan District, because it has a low TFR number compared to other districts. Population Control and Family Planning Department Sibolga, Sibolga city, Sibolga sambas.

The steps taken by Population Control and Family Planning Department to improve the Family Planning Center in 3 other districts are to carry out direct monitoring by sharing a team to prevent reports that are not in accordance with events on the ground. The results of a study conducted by Hutanto, et al (2014) stated that the Family Planning Field Officers performance was affected by the work discipline of field officers who often violated things such as being late for work, leaving the workplace without reason.

The above steps can be used as an alternative to improve the performance of PLKB. Along with these steps, the PLKB must also increase activities in accordance with the work plan that has been made and conduct counseling to regions that have never been reached, this will optimize the performance of the PLKB and reduce the occurrence of reports that are not in accordance with reality on the ground.

The next phenomenon that was discovered from the results of the study was related to the number of Family Planning Field Officers that had exceeded the standard. This is due to the lack of planning made for the work steps that must be done by Family Planning Field Officers and the absence of sanctions if Family Planning Field Officers does not meet the agreed PPM. Report gaps occur in the field with Population Control and Family Planning Department Office in Sibolga. Based on the results of in-depth interviews due to the fact that there are still new Family Planning Field Officers that do not understand how to fill out reports.

Based on the results of research obtained from the community, said there were still people who had never been visited by Family Planning Field Officers, had never analyzed Family Planning Field Officers on duty in their area. This is caused by Family Planning Field Officers still conveying information only in urban areas, while people who live on the slopes of the mountain are still not aware of Family Planning Field Officers in their area. Many urban 
communities also still do not understand about the impact of family planning which was conveyed by Family Planning Field Officers when counseling.

The results of the study (Indrawati, et al 2012) stated that the low communication skills of implementing staff at the field level (PKB) in providing counseling about family planning issues could affect the increase in the number of family planning participants.

\section{Conclusion}

Based on the results and discussion of conclusions in this study, the performance of family planning field officers in Population Control and Family Planning Department Sibolga is still not optimal. This is marked by the performance evaluation carried out and monitored only through social media chat groups, but the implementation of direct monitoring is still not good, there are gaps in report data in the field found by the difference in the number of KB participants in the field with the number of Family Planning participants in Population Control and Family Planning Department, delays in sending reports, the number of human resources has exceeded the provisions but the TFR target has not been achieved, Family Planning Field Officers skills in counseling are still lacking, Family Planning Field Officers work discipline is still often violating things such as being late for work and leaving the workplace without a clear reason.

Population Control and Family Planning Department should routinely conduct monitoring by going directly to the Family Planning Healing Center. Population Control and Family Planning Department provides training to Family Planning Field Officers in counseling skills. Local governments are expected to give rewards to districts that have a low TFR. Family Planning Field Officers should conduct regular outreach to the community regarding family planning programs in terms of reducing the TFR rate. It is hoped that Population Control and Family Planning Department will impose strict sanctions for Family Planning Field Officers who lack discipline.

\section{References}

Afniyanty, 2016. Kinerja Petugas Lapngan Keluarga Berencana (PLKB) di Desa Pakawa Kecamatan Pasangkayu Kabupaten Mamuju Utara. Jurnal katalogis April 2016

Badan Keluarga Berencana dan Pemberdayaan Perempuan, 2016. RENSTRA Tahun 2016-2021. Sibolga

BKKBN Kota Sibolga. 2016. Profil Hasil Updating Pendataan Keluarga Kota Sibolga Tahun 2016. Sibolga

BKKBN Provinsi Sumatera Utara. 1999. Informasi Mengenai Takesra dan Kukesra Buku Pegangan Petugas Lapangan. Medan

Bogdan, Robert dan Steven J Taylor. 1993. Kulaitatif-Dasar-Dasar Peneltian. Surabaya: Usaha Nasional.

Bungin, Burhan. 2011. Penelitian Kualitatif. Jakarta: Kencana Predana Media Group.

Dewi, Sri Ropika. 2012. Determinan Pemakaian Alat Kontrasepsi Pada Wanita PUS Di Wilaya Puskesmas Kota Blangkejeren Kabupaten Gayo Lues. Medan: Tesis Fakultas Kesehatan Masyarakat Universitas Sumatera Utara

Dinas Pengendalian Penduduk dan Keluarga Berencana. 2017. Profil Hasil Updating Pendataan Keluarga Kota Sibolga Tahun 2017. Sibolga

Indrawati, Wulandari; Muchtar Erman,2012. Pelaksanaan Fungsi Petugas Lapangan Keluarga Berencana (PLKB) Dalam Meningkatkan Jumlah Peserta KB di Kelurahan Langgini Kecamatan Bangkinang Kabupaten Kampar Tahun 2011-2012. Jurnal. Pekanbaru. Kampus Bina Widya Km, 12,5 Simpang Baru Panam Meilani, Niken dan Nanik 
Setiyawati, Deviana Estiwidani, Suherni. 2010. Pelayanan Keluarga Berencana. Yogyakarta: Fitramaya.

Miles, B. Mathew dan Michael Huberman. 1992. Analisis Data Kualitatif Buku Sumber Tentang Metode-metode Baru. Jakarta: UIP.

Mulyani, N.S, dan Mega Rinawati. 2013. Keluarga Berencana dan Alat Kontrasepsi. Jakarta: Nuha Medika

Pinem, Saroha. 2009. Kesehatan Reproduksi dan Kontrasepsi. Jakarta: Trans InfoMedia.

Proverawati, Atikah dan Anisah Dwi Islaely, Siti Aspuah. 2010. Panduan Memilih Kontrasepsi Yogyakarta: Nuha Medika.

SDKI, 2017. Survei Demografi Kesehatan Indonesia. Jakarta.

Suratun, dan Sri Maryani, Tien Hartini, Rusmiati, Saroha Pinem. 2008. Pelayanan Keluarga berencana \& Pelayanan Kontrasepsi. Jakarta: Trans Info Media.

Undang - Undang RI Nomor 52 Tahun 2009 tentang Perkembangan Kependudukan dan Pembangunan Keluarga.

Yuhedi, Lucky Taufika dan Titik Kurniawati. 2014. Kependudukan dan Pelayanan KB.Jakarta: EGC

Zuhriyah, Laitus, 2012. Revitalisasi Peran Petugas Lapangan Keluarga Berencana (PLKB) dalam Mengingkatkan Peserta KB di Kecamatan Banyumanik Kota Semarang. Tesis Fakultas Kesehatan Masyarakat Universitas Diponegoro 